\title{
NUMERICAL STUDY OF CONFINEMENT EFFECT OF FRP COATINGS ON BEHAVIOR OF RC FRAMES BY USING NONLINEAR ANALYSIS
}

\author{
Hossein Tahghighi'*, Mohammad Rashid Gholami' \\ University of Kashan, Kashan, Islamic Republic of Iran
}

Confinement of both existing and newly constructed reinforced concrete $(R C)$ frames by fibre reinforced polymer $(F R P)$ has been commonly used in recent decades. This is because of its ability to enhance the behavior of $R C$ frames under lateral loading. The purpose of this research is to perform a numerical study on effect of FRP confinement on strength and ductility of RC frames using OpenSEES software.After evaluating the accuracy of numerical model results by comparison with experimental results, the behavior of FRP-resistant frames is discussed. The 8-story studied building is reinforced in various ways by GFRP and CFRP composite sheets. Results of nonlinear analysis show that un-wrapped frame exhibits low resistance and less energy absorption. However, the loading capacity and the performance level have improved significantly in the frames strengthened with FRP materials.Also, increased capacity and reduced drift present more amount of increment in cases which CFRP materials are used.

Key words: Reinforced concrete, FRP materials, Confinement, Flexural retrofitting, Nonlinear analysis

\section{INTRODUCTION}

The widespread destructions of concrete structures in past earthquakeshave shown that identification and strengthening of vulnerable structures gain more importance in order to mitigate human and economic casualties.A comprehensive overview of traditional seismic rehabilitation techniques was presented by FEMA-547 [1]. Conventional techniques which utilize braces, jacketing or infills, as well as more recent approaches including base isolation and supplemental damping devices, have been considered to strengthen the building and as such improve its behavior. In the past decade, an increased interest in the use of advanced nonmetallic materials has been reported.

Among the variousrehabilitation methodsin $\mathrm{RC}$ buildings, the use of Fiber Reinforced Polymers(FRP) has been widely considered in recent years.FRP is a compound material with very high tensile strength which consists of two parts. The first part consists of fibers that are the load bearing part toburden of bearing loads. The adhesive or resin forms the second part, where gains the role of maintaining the fibers together and transferring power to all parts. Typical types of FRP used in structural reinforcement are carbon (CFRP) and glass (GFRP). Other advantages of FRP materials include low specific gravity, high corrosion resistance and ease of use. Where disadvantages are sudden failure and its vulnerability to fire and heat.

FRP materials are used to increase confinement, which is a desired and favorable condition in concrete.Therefore, the tension-strain behavior of concrete confined with FRP improves and increases significantly [2-6].FRP confinement causes the performance of concrete columns to increase significantly due to improved specification of confinedconcrete.Saadatmanesh et al. [7] performed a test on 5 circular RC columnsfrom base of a bridge. The samples were designed to comply with bridge seismic regulations ofbefore 1971and the area with high earthquake risk. Test results showed thatstrength and ductility increased significantly incolumns which were wrappedby GFRP composite strips in the plastic hinge area.Chaallal et al. [8] studied the effects of concrete strength characteristics, ratio of length to column section widthand number of CFRP layers on confinement by examining 90 short columns with square and rectangular sections under axial load.They showed that confinement in both cross sections increased compressive strength and ductility, although this is less than of circular columns. They also showed that increase in number of layers improved the performance of column and this performance in columns with low-strength concrete was betterthan columns with normal-strength or high-strength concrete.

Balsamo et al. [9] conducted a study on a four-story RC frame with columns and beams covered with FRP.Their research showed that the frame wrapped with FRP could withstand against an earthquake 1.5 times the design earthquake intensity.In experimental studies by De Luca et al. [10], the effect of FRP sheets on axial force and column deformation was investigated.In these studies, several RC columns with square and rectangular sections were constructed in real scale and were rehabilitated with FRP sheets of glass and basalt and were applied under pure axial load.It should be noted that these specimens were designed according to the regulations of the 70's. The results of mentioned studies showed that although FRP sheets increase the axial strength of concrete, but they are more effective in increasing the concrete strain capacity. 
The study by Wang et al. [11] provides test data and relevant analysis on seismic behavior of deficient circular RC columns wrapped with CFRP under high axial load. Their experimental results indicated that the use of CFRP resulted in remarkable improvement in ductility, energy dissipation, and strength of the deficient lateral confinement RC columns. In another study, Ronagh and Eslami [12] used FRP to confine columns at the critical zones of an 8-storey poorly-confined frame. Their analytical results showed that the seismic performance and ductility increased substantially. Following the aforementioned researches, the purpose of this paper is to study the behavior of RC structures strengthened with FRP. FRP sheets have been used to increase the flexural strength of buildings whichinclude the possibility of plastic hinge. One of the objectives of present study is to compare the effects of type and condition of FRP coating on force capacity and displacement of RC frames. Therefore, GFRP and CFRP materials are used in different conditions includingfully FRP-covered frames, covered only in beams, covered only in columns and covered only in plastic hinge areas. It should be mentioned that studied models are evaluated by nonlinear static analysis (Pushover) with the help of OpenSEES software [13].

\section{STRESS-STRAIN MODELS OF FRP-CONFINED CONCRETE}

The first stress-strain models of concrete encapsulated by FRP were obtained from developing the models provided for steel-confined concrete by Mander and Priestley [14]. However, the researchers later concluded that development of confined models made for steel are not suitable for FRP-confined columns, due to the different mechanical properties of steel and FRP. For this reason, distinctbilinear models are provided for stress-strain curve of concrete confined with FRP [2, 3].Besides, other different stress-strain models have been proposed by other researchers, where in most of them behavior of FRP-confined concrete is assumed to be in the same upstream branch as notconfinedconcrete [6-4].This is considered since of insignificance confinement provided by FRP due tolow side-strain ofconfined concrete atinitial loading stages.

Lam and Teng [15] proposed a new design-oriented stress-strain simple model for concrete confined by FRP wraps with fibers only or predominantly in the hoop direction based on a careful interpretation of existing test data and observations. In the meantime, this model captures all the main characteristics of the stress-strain behavior of concrete confined by different types of FRP. In addition, for unconfined concrete, this model reduces directly to idealized stress-strain curves in existing design codes. The basic assumptions of this simple model are: (i) the stress-strain curve consists of a parabolic first portion and a straight line second portion, as given in Figure 1 ; (ii) the slope of the parabola at $\varepsilon c=0$ (initial slope) is the same as the elastic modulus of unconfined concrete Ec; (iii) the nonlinear part of the first portion is affected to some degree by the presence of an FRP jacket; (iv) the parabolic first portion meets the linear second portion smoothly (i.e. there is no change in slope between the two portions where they meet); (v) the linear second portion ends at a point where both the compressive strength and the ultimate axial strain of confined concrete are reached.

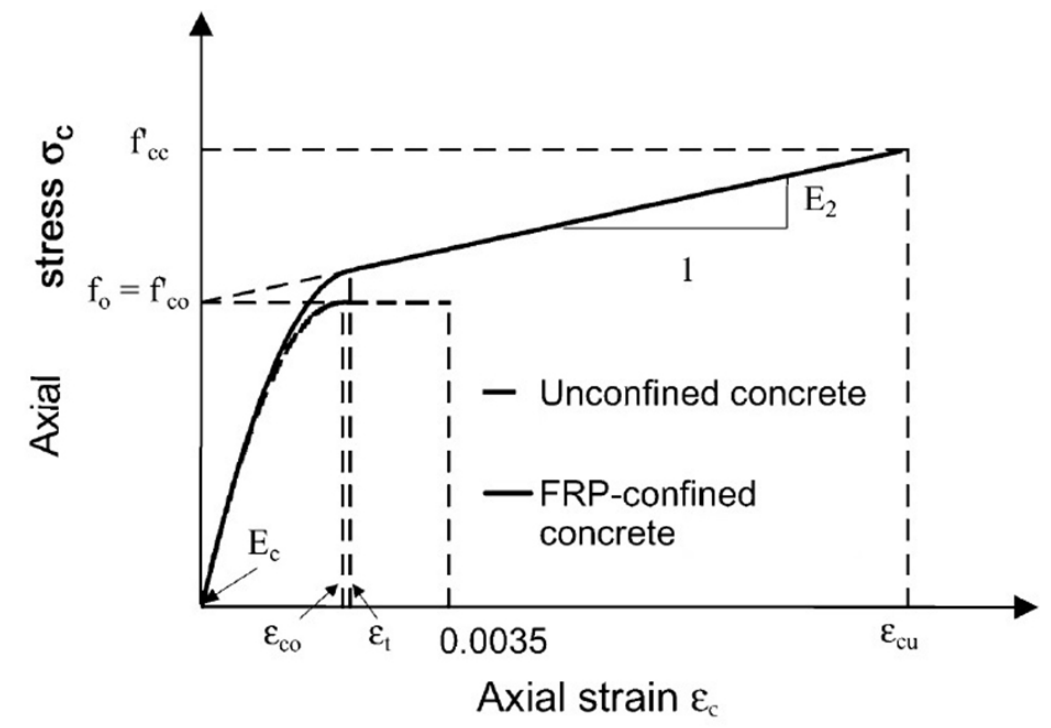

Figure 1: Stress-strain relationship for FRP confined concrete [after 15]. 
Based on the assumptions listed above, the proposed stress-strain model for FRP-confined concrete is given by the following expressions:

$$
\sigma_{c}=\left\{\begin{array}{c}
E_{c} \varepsilon_{c}-\frac{\left(E_{c}-E_{2}\right)^{2}}{4 f_{o}} \varepsilon_{c}^{2} \quad 0 \leq \varepsilon_{c} \leq \varepsilon_{t} \\
f_{o}+E_{2} \varepsilon_{c} \varepsilon_{t} \leq \varepsilon_{c} \leq \varepsilon_{c u}
\end{array}\right.
$$

where $\varepsilon_{c}$ is axial strain, fo is the intercept of the stress axis by the linear second portion, $\varepsilon c u$ is the ultimate strain. The parabolic first portion meets the linear second portion with a smooth transition at $\varepsilon_{\mathrm{t}}$, which is given by:

$$
\varepsilon_{t}=\frac{2 f_{0}}{E_{c}-E_{2}}
$$

where $E_{2}$ is the slope of the linear second portion, given by:

$$
E_{2}=\frac{f_{c c}-f_{0}}{\varepsilon_{c c}}
$$

where $f_{c c}$ is compressive strength of confined concrete.

\section{STUDIED REINFORCED CONCRETE BUILDINGS}

In current paper, an 8-story RC structure is studied with a moment frame system that is strengthened invarious ways with CFRP and GFRP materials.

\section{Original RC Frame}

In this section, the building of primary RC Frame is introduced, such that one of its internal frames is used for analysis. The studied 8-story moment frame has three spans of 5 meters in length, where distance between frames and height of floors are 5 and 3 meters, respectively.Concrete design of building is carried out by [12] and based on average ductility criteria of $\mathrm{ACl} 02-318$ [16].Figure 2 represents the plan and view of building. Further, Figure 3 and Table 1 depict the dimensions and details of reinforcement in beams and columns of 8-story RC moment frame, where designdead load and live loadare 10 and $30 \mathrm{kN} / \mathrm{m}$, respectively.Concrete compressive strength ( ) and rebar yield strength (fy) are considered as $25 \mathrm{MPa}$ and $420 \mathrm{MPa}$.Moreover,shear reinforcement steel bars are chosen of $10 \mathrm{~mm}$ diameter.Assuming that the building is located in type III soil and region with high seismic hazard, seismic loads arecalculated in accordance with the 2800 regulation [17].Due to the regularity of building, torsional effects of seismic loads are ignored.

Table 1: Beams, Columns and reinforcement details of the studied frame

\begin{tabular}{|c|c|c|c|c|c|c|c|c|c|}
\hline Element & $\begin{array}{c}\text { Story } \\
\text { No. }\end{array}$ & $\begin{array}{c}\mathrm{B} \\
(\mathrm{mm})\end{array}$ & $\begin{array}{c}\mathrm{H} \\
(\mathrm{mm})\end{array}$ & $\begin{array}{c}\mathrm{D} \\
(\mathrm{mm})\end{array}$ & $\begin{array}{c}\mathrm{d}^{\prime} \\
(\mathrm{mm})\end{array}$ & Ast & As & A's & $\begin{array}{c}\text { Transverse } \\
\text { Steel spacing }\end{array}$ \\
\hline \multirow{5}{*}{ Column } & 1,2 & 600 & 600 & 540 & 60 & $16 \varnothing 25$ & - & - & 150 \\
& 3,4 & 600 & 600 & 540 & 60 & $16 \varnothing 18$ & - & - & 150 \\
& $5,6,7,8$ & 500 & 500 & 540 & 60 & $16 \varnothing 16$ & - & - & 125 \\
\hline \multirow{3}{*}{ Beam } & $1,2,3,4$ & 500 & 500 & 540 & 60 & - & $6 \varnothing 25$ & $4 \varnothing 25$ & 100 \\
& 5,6 & 500 & 500 & 540 & 60 & - & $6 \varnothing 22$ & $4 \varnothing 22$ & 100 \\
& 7,8 & 500 & 500 & 540 & 60 & - & $6 \varnothing 18$ & $3 \varnothing 18$ & 100 \\
\hline
\end{tabular}

Table 2: Mechanical properties of composite sheets [10,18]

\begin{tabular}{|c|c|c|c|c|}
\hline $\begin{array}{c}\text { Composite } \\
\text { type }\end{array}$ & $\begin{array}{c}\text { Tensile strength, } \\
\mathrm{f}_{\mathrm{r}}(\mathrm{MPa})\end{array}$ & $\begin{array}{c}\text { Ultimate tensile } \\
\text { strain, } \mathrm{E}_{\mathrm{fr}}\end{array}$ & $\begin{array}{c}\text { Tensile modulus, } \\
\mathrm{E}_{\mathrm{f}}(\mathrm{MPa})\end{array}$ & $\begin{array}{c}\text { Thickness, } \\
\mathrm{t}_{\mathrm{f}}(\mathrm{mm})\end{array}$ \\
\hline CFRP & 3900 & 0.0155 & 240000 & 0.165 \\
GFRP & 3241 & 0.045 & 72397 & 0.589 \\
\hline
\end{tabular}

\section{FRP-strengthened RC frame}

In following study, both GFRP and CFRP composites are used to compare the efficiency of FRP materials in strengthening of RC structures. In accordance with design philosophy of poor beam-strong column in seismic design codes, bending capacity of columns at junction of beam to column should be greater than total bending strength of beams. To meet this requirement, Tables 2 and 3 represent the characteristics and number of required GFRP and CFRP composite sheets in frame 432 members, respectively.According to Table 3, the thickness of composite sheets in beams and columns is considered to be same, but forfifth and sixth floors' column which requiremore sheets.Moreover, to create equal modeling conditions, the number of FRP layers is calculated in such a way that the strength of GFRP and CFRP materials be equal.In other words, the product of tensile modulus (Ef), ultimate tensile strain (Efr) and thickness (tf) of a composite should be equal to other composite's tensile strength (fr). 


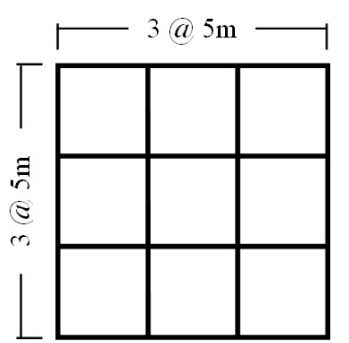

(a)

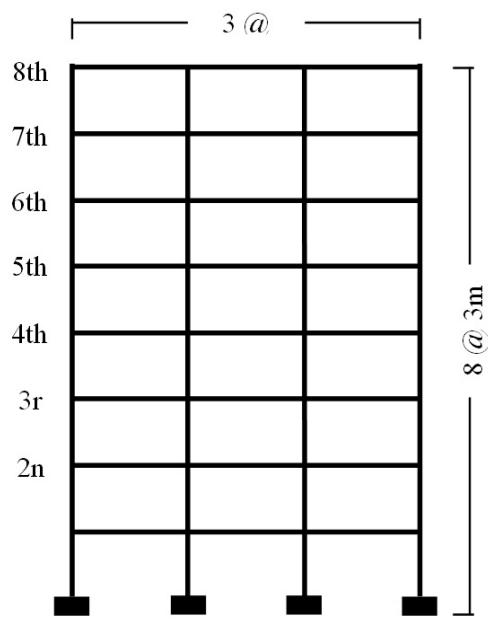

(b)

Figure 2: Configuration of RC building model: (a) plan and (b) elevation

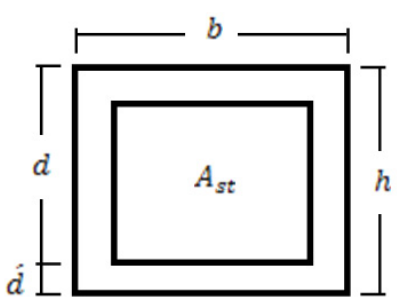

(a)

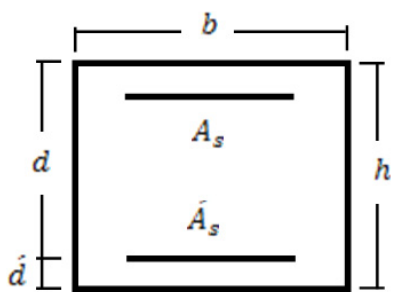

(b)

Figure 3: Typical sections: a) column and b) beam [after 12]

It is worth pointing out, by assuming a proper method for implementation of FRP coatings, the separation of com-

posite sheets in modeling has been neglected [19].

Table 3: Number of composite sheets in the GFRP and CFRP retrofitted frame [12]

\begin{tabular}{|l|llll|llll|}
\hline Element & \multicolumn{4}{|c|}{ Columns } & \multicolumn{4}{c|}{ Beams } \\
\hline Story No & $7-8$ & $5-6$ & $3-4$ & $1-2$ & $7-8$ & 6 & 5 & $1-4$ \\
\hline No. of GFRP layers & 4 & 4 & 2 & 2 & - & - & 2 & 2 \\
No. of CFRP layers & 6 & 9 & 6 & 6 & - & 6 & 6 & 6 \\
\hline
\end{tabular}

\section{NUMERICAL ANALYSIS}

Concrete, steel and FRP are introduced using uniaxial materials by parameters such as compressive strength, strain, modulus of elasticity and yield stress. According to Figure 4, for introduction of concrete, the uniaxialMaterial Concrete 01 command is used based on the Kent-Park model [20] and the steel02 uniaxialMaterial command is employed for longitudinal reinforcement, based on the Giuffre-Menegotto-Pinto model [13].In addition, the Lum and Tang model [15] has been applied for the concrete enfolded with FRP. It is necessary to explain that the effect of number and spacing of transversal reinforcements or crumbs is taken into account by using the amount of confinement in concrete whichseparates the concrete into confined and unconfined parts.After the introduction of required materials, fiber section is hired to describe the beams and columns.As displayed in Fig. 5, sections wrappedwith FRP materials consist of 3 parts, including FRP coating, confinedconcrete with cross-reinforcement (concrete core) and concrete confined with FRP (concrete coating) and finally, a nonlinear beam-column element with widespread plasticity distribution is utilized for definition of beam and column elements [13].

The analyzes of present work were carried out using non-linear static analysis method (Pushover) in OpensEES [13].In Pushoveranalysis, the gravity load is assumed to be constant and the lateral load is applied to the structure gradually increasing as long as the displacement of control point is achieved to the target value. Besides, the total dead load plus $20 \%$ of live load is considered in Pushover analysis in accordance with Iran's seismic regulation[17], where reverse triangular distribution in height was considered as lateral load model. 


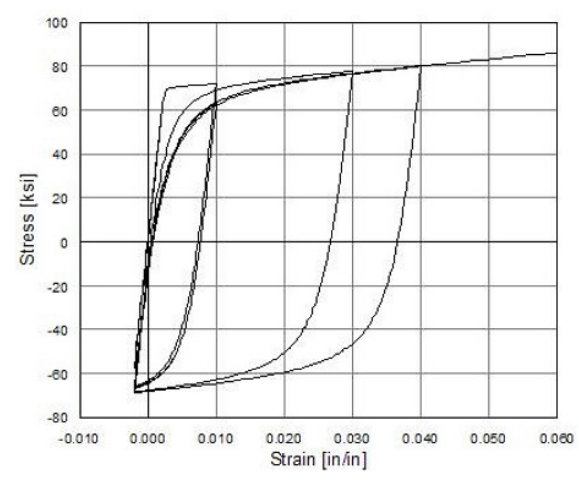

(a)

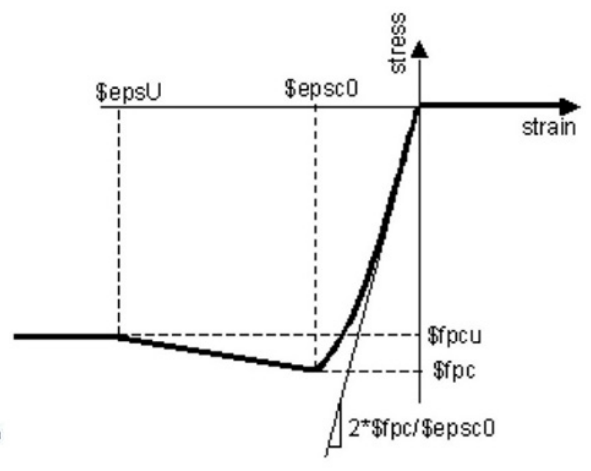

(b)

Figure 4: The stress-strain relationship for: a) Concrete02 material and b) Steel02 material [13]

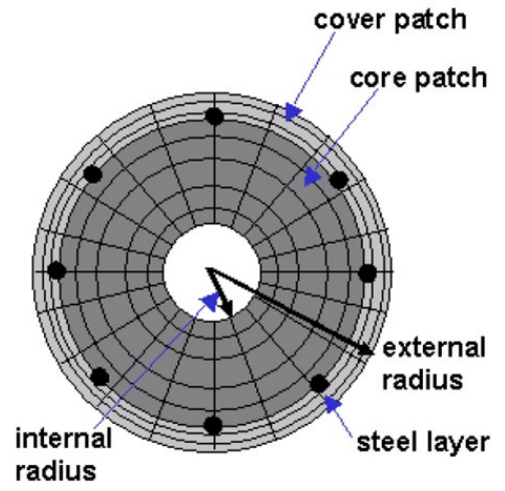

Figure 5: An example fiber section [13]

Further, the P- $\Delta$ effect in OpenSEES software is considered by using the geomTransf PDelta command in nonlinear analyzes.

For a comprehensive nonlinear analysis, consideration of the shear failure in members is necessary. However, past studies have reported that even for under-designed RC buildings, the shear demand is significantly lower than the shear capacity in both beams and columns and that no shear failure would occur [21, 22]. Therefore, in this study, only inelastic flexural behavior of structural elements was considered through concentrated rigid plastic hinges at the ends which are susceptible to inelastic behavior.

Obviously, nonlinear time history analyses may provide most capabilities to explore FRP strengthening effects for RC buildings. Furthermore, earthquake ground motions close to a ruptured fault can be significantly different from far-fault records. Near-fault motions are noticeably influenced by the forward directivity when the fault rupture propagates toward a site [23, 24]. Mortezaei et al. [25] presented the results of typical existing RC buildings subjected to far-fault and near-fault ground motions and the potential improvements achievable after FRP retrofitting of the buildings. Thus, the detailed evaluation of the effect of FRP rehabilitation on the seismic performance of existing $R C$ buildings against comprehensive earthquake ground motion database can be a matter of further research.

\section{VERIFICATION EXPERIMENTS}

In current section, multipleexperimental samples ofRC column confined with CFRP materials are introduced firstly and then the analysis results of numerical model are evaluated and compared withexperimental results.

\section{Introducing experimental samples}

The studied columns consist of 8 circular RC columns on a scale of one-third which their reinforcement details were designedin accordance withregulations' criteriaof 80 's. [11]Two RC columns without FRP strengthening were used as control samples to evaluate the effect of CFRP-retrofitting on six other rehabilitated columns in plastic hinge area, whereall columns have a diameter of $180 \mathrm{~mm}$ and length of $1260 \mathrm{~mm}$. The concrete coating thickness is $8 \mathrm{~mm}$ and six longitudinal bars of $12 \mathrm{~mm}$ diameterand cross-sectional reinforcement of 4 $\mathrm{mm}$ diameter are utilized incolumn. In addition, spacing of transverse reinforcement inmiddlespan and at both ends ofsamples are $120 \mathrm{~mm}$ and $60 \mathrm{~mm}$, respectively.It is worth noting that CFRP coatings with different lengths are wrapped on smooth and polished surface of column. Column details,specimens' specificationsandcharacteristics ofmaterials used forcolumns are representedin Figure 6 and Tables 4 and 5, correspondingly. 


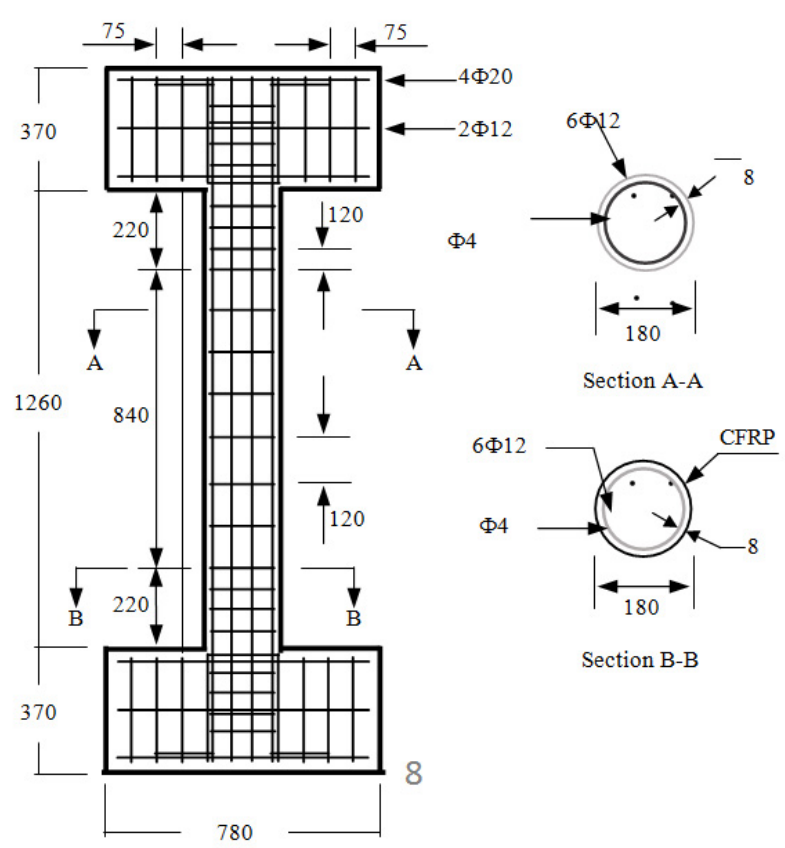

Figure 6: RC column specimens details, mm [after 11]

Table 4: The details of test specimens [11]

\begin{tabular}{|c|c|c|c|c|}
\hline Specimens & $\begin{array}{c}\mathrm{f}_{\mathrm{c}}^{\prime} \\
(\mathrm{MPa})\end{array}$ & ${\mathrm{P} / \mathrm{f}_{\mathrm{c}}{ }^{\prime} \mathrm{A}_{\mathrm{g}}}^{\prime}$ & $\begin{array}{c}\text { wrapping } \\
\text { length } \\
(\mathrm{mm})\end{array}$ & $\begin{array}{c}\text { Retrofit } \\
\text { detail }\end{array}$ \\
\hline $\mathrm{C}_{1}$ & 54.8 & 0.45 & - & Control \\
$\mathrm{C}_{2}$ & 71.2 & 0.45 & - & Control \\
$\mathrm{C}_{1} \mathrm{n}_{1}$ & 54.8 & 0.45 & 200 & 4-layer \\
$\mathrm{C}_{1} \mathrm{n}_{2}$ & 54.8 & 0.55 & 320 & 4-layer \\
$\mathrm{C}_{1} \mathrm{n}_{3}$ & 54.8 & 0.65 & 320 & 4-layer \\
$\mathrm{C}_{2} \mathrm{n}_{1}$ & 71.2 & 0.45 & 200 & 4-layer \\
$\mathrm{C}_{2} \mathrm{n}_{2}$ & 71.2 & 0.55 & 320 & 4-layer \\
$\mathrm{C}_{2} \mathrm{n}_{3}$ & 71.2 & 0.65 & 320 & 4-layer \\
\hline
\end{tabular}

Table 5: Material properties of the test specimens [11]

\begin{tabular}{|c|c|c|c|}
\hline Materials & Yield strain & $\begin{array}{c}\text { Tensile modulus } \\
\text { (GPa) }\end{array}$ & $\begin{array}{c}\text { Tensile strength } \\
\text { (MPa) }\end{array}$ \\
\hline $\begin{array}{c}\text { Longitudinal } \\
\text { steel }\end{array}$ & 0.00179 & 198 & 354 \\
Hoop & 0.002 & 201 & 402 \\
CFRP & 0.018 & 230 & 3430 \\
\hline
\end{tabular}

\section{Validation of numerical models}

Figures 7 and 8 displayPushover curves obtained from experimental results [11] and simulation ofpresent work for all un-wrapped and wrapped columnsfor concrete compressive strength of 54.8 MPa (type C1) and 71.2 $\mathrm{MPa}$ (type C2), respectively.As it can be seen, unwrapped circular concrete columns bear a slight displacement indicating they are brittle, where in the case of $\mathrm{RC}$ circular columnsrehabilitated with FRP materialsthe displacement has increased, which impliesmoreductility. Besides, by increasing axial load, maximum lateral load of strengthened columns increases. Another worth-mentioning point is, with increase of coating length in circular FRP-strengthened RC columns the strength increases as well. In addition, higher compressive strength ofconcrete makes the FRP-rehabilitated columnsmore durable against base shear. 


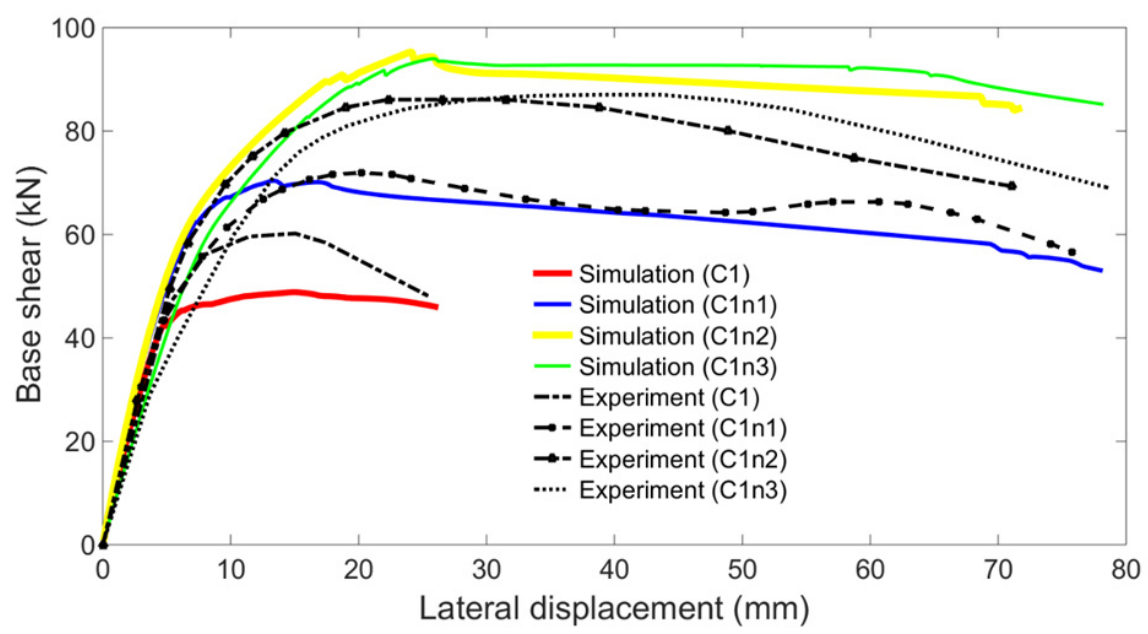

Figure 7. Comparison of capacity curves from finite element modeling technique with experiments of wrapped and unwrapped $R C$ columns $\left(f_{c}^{\prime}=54.8 \mathrm{MPa}\right)$

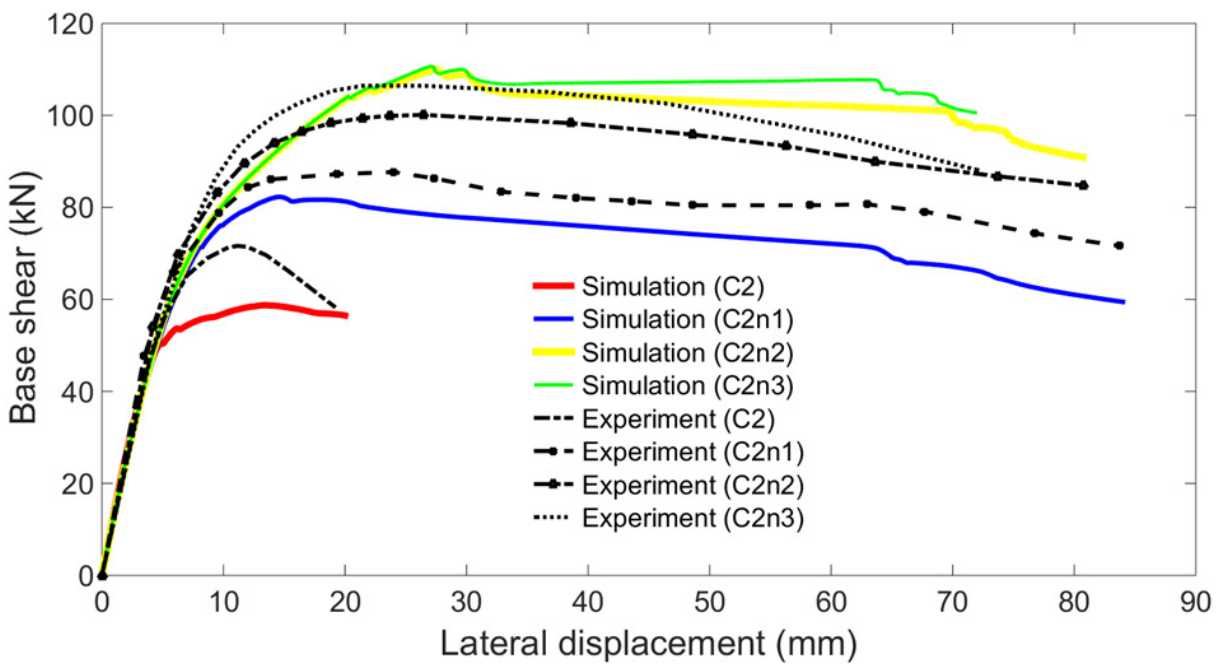

Figure 8. Comparison of capacity curves from finite element modeling technique with experiments of wrapped and unwrapped $R C$ columns $\left(f_{c}^{\prime}=71.2 \mathrm{MPa}\right)$

\section{RESULTS AND DISCUSSION}

Pushover analysis results of RC frames confined by various types of CFRP and GFRP materials described in Section 3 are compared and discussed in following sections.

\section{Comparison of capacity in un-wrappedframes with wrappedones}

Curves of Pushover analysis inframes rehabilitated with GFRP and CFRP compared to the conventional frame are demonstrated in Fig. 9.As represented in Figure 7, there is a significant increase of load capacity and bearing strength in FRP-wrapped frames, compared to the original frame, where indicates the high efficiency of these material. Therewith, CFRP-reinforced frame is more resistant and shows higher bearing capacity (load bearing) compared to the GFRP- rehabilitated frame, which is due to higher tensile strength of carbon fiber than glass fiber.

\section{Comparison of CFRP effect on beams and columns}

In current section, results of CFRP-wrapped RC frame's retrofitting are examined in three different methods, which include totalstrengthened of all beams and columns in frame, strengthened only in beams and strengthened only in columns, while it is assumed that cracking does not occur in beam-column joint area.As Figure 10 shows, enhancement of strength and stiffness is higher in only-columns strengthened frame thanonly-beams strengthened frame. Even though, use of CFRP simultaneously in beams and columns increases the strength and stiffness of frame much more. This suggests that simultaneous use of FRP materials in beams and columns is more effective than only one of them hired in retrofitting. 


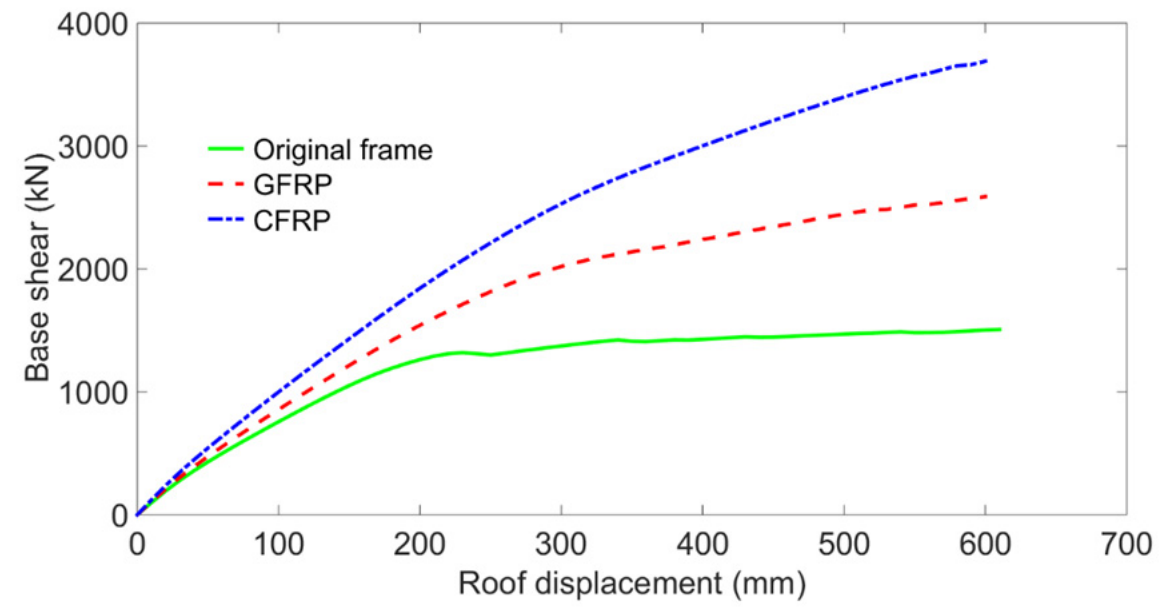

Figure 9: Comparison of pushover curves of the original and rehabilitated 8-story frames (fully wrapped FRP)

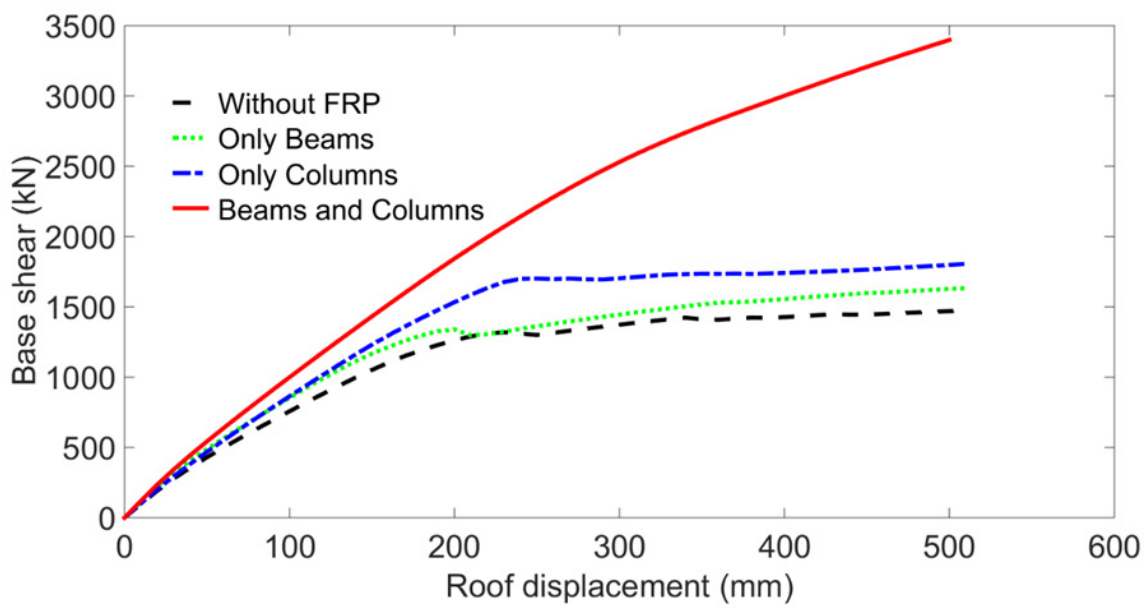

Figure 10: Comparison of pushover curves of the original and three different types of the rehabilitated 8-story frames

\section{Comparison of CFRP coating effect on plastic hinges}

The other cases studied in this researcharecomparison of capacity curve instrengthened frame's plastic hinge areaswith capacity of a frame which its total members have been rehabilitated with CFRP materials. Hence, the modeling of these two methods in OpenSEES software is almost identical, with a single difference in connection-strengthenedframe model in whicheach frame element (beamand column) is divided into three parts, including one part in middle ofelement without FRP and two FRP-covered parts at beginning and end of element (joints), wherethe plastic hinges are made.The minimum length of CFRP coating at plastic hinge's formation area is usually considered equal to beam depth [12]. Howbeit,length of applied composite sheets in beams and columns is defined 1.5 times the thickness of beam $(75 \mathrm{~cm})$ in this study, in order to eliminate the possibility of plastic hinge's displacement. Thus, the schematic design ofstrengthening inframe's joint areas is depicted in Figure 11.
Further, Figure 12 displayspushover curves of the frame rehabilitated with CFRP in joints and throughout the frame.It can be observed that although the frame overall retrofitted with CFRP in beams and columnshas a higher resistance than framerehabilitated only in joints, but this increment is not significant, implying that in order to save time and money, it is possible to ignore the slight increase in overall strengthening and only beam-column joints strengthening using FRP materials.

\section{Comparison of driftin wrapped and un-wrapped frames}

Effect of FRP use on relative drift of RC frame's floors is studied such thatan 8-story un-wrapped frame has been compared with two cases wrapped by glass and carbon fiber. According to Figure 13,floordriftof FRP-wrapped frames has been reduced significantly. While, this reduction is higher in frame with carbon fiber than the glass fiber frame. As shown in Fig. 13, the drift in un-wrapped frame has exceeded the proposed $2.5 \%$ allowable limit in seismic regulations [17] and reached up 3.5\%. 


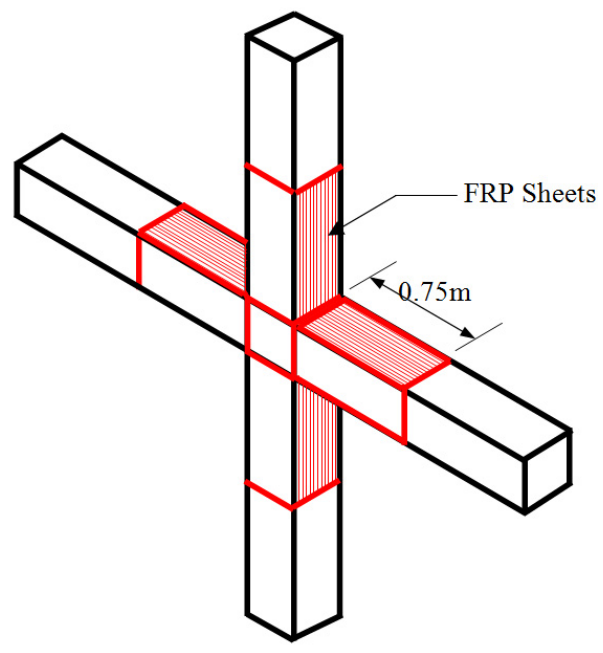

Figure 11: Scheme of FRP strengthening in an interior joint [after 12]

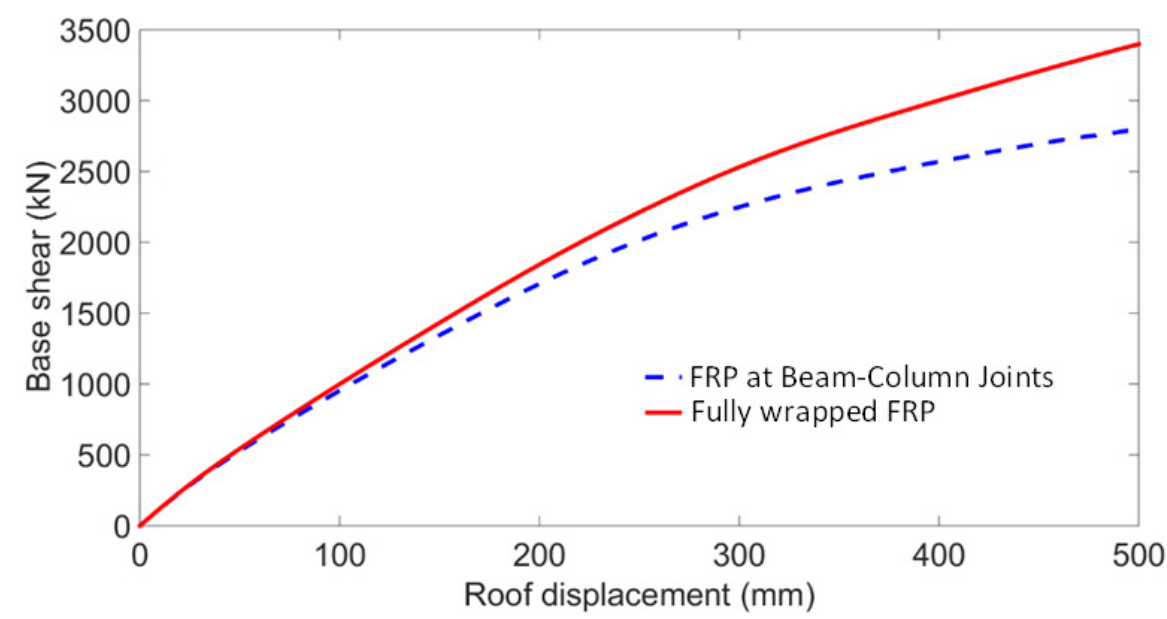

Figure 12: Comparison of pushover curves of the rehabilitated 8-story frames

Besides, in FRP-wrapped frames, drift is reduced and within the permitted range, indicating the effective effi- ciency of FRP materials in improving the performance of rehabilitated frames.

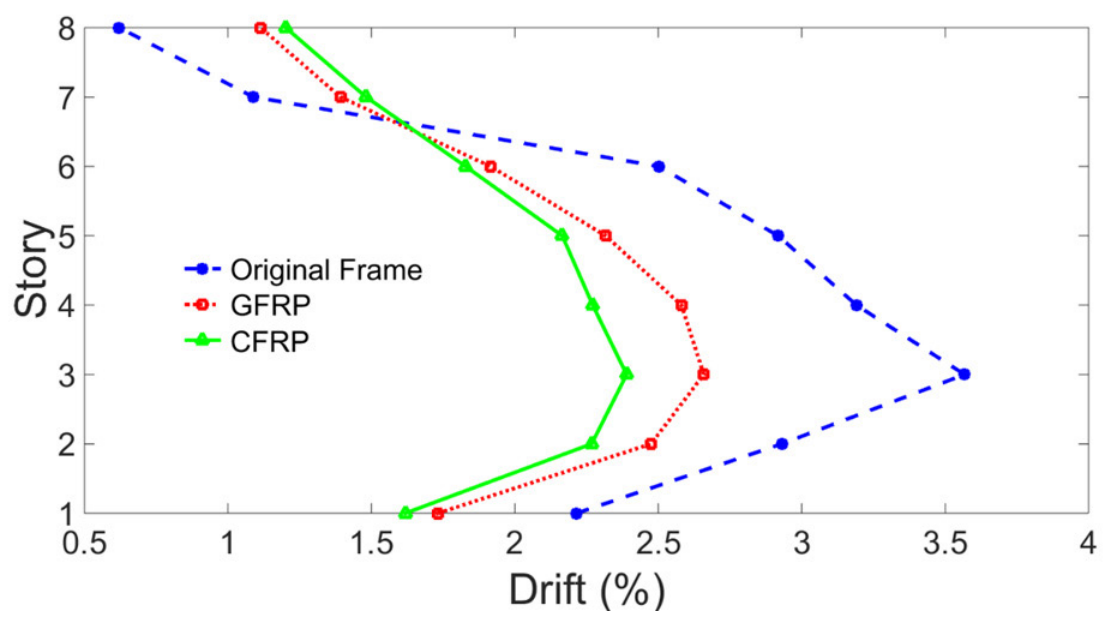

Figure 13: Comparison of inter-story drifts of the original and rehabilitated 8-story frames (FRP at joints) 


\section{CONCLUSIONS}

In currentresearch, results of nonlinear analysis of RC frames are presented in OpenSEES finite element software, regarding confinement effect of concrete which is due toaction oftransversal bar onbeam and column and covering effect ofFRP in four modes of coverage in column total height, beam total length, simultaneous beam and column total lengthand finally coating only in plastic zones of beam and column.Verification of numerical model in column specimens showed that stress-strain modelis able to determine the capacity curves of wrapped concrete, under axial and lateral loadings. The results of analysis are presented with aim of comparing the effect of confinement methods on frame behavior, which several outstanding results are referred in following:

1. FRP coating in plastic joints area improves ductility and energy absorption ofcolumns. Thus, bygreater length ofFRP coating,strength and ductility ofcolumns rises up to some extent.

2. Strength incrementin beams and columns that are overall wrapped with FRP is not remarkable in comparison to the one that is reinforced in only plastic hinge. Therefore, it is possible to ignore the overall retrofitting of frame members due to cost saving.

3. CFRP-reinforced frames increase the strength of structure more than the frames strengthened with GFRP materials.

4. Simultaneous strengthening of RC framesby FRP materials in beams and columns perform better than only-beams or only-columns strengthening.

5. Inter-story drifts decrease in frames rehabilitated with glass and carbon fiber, which leads to a structure with a more ductile behavior.In addition, drift reduction is greater when using carbon fiber.

\section{ACKNOWLEDGMENTS}

The authors would like to thank M. Alborzi for valuable comments on the numerical analyses and great help during this research.Discussions with $\mathrm{M}$. Forughi are also appreciated.

\section{REFERENCES}

1. [FEMA-547. Techniques for the Seismic Rehabilitation of Existing Buildings. Federal Emergency Management Agency (FEMA), USA, 2006.

2. Xiao, Y., Wu, H. Compressive behavior of concrete confined by carbon fiber composite jackets. Journal of materials in civil engineering, 12 (2): 139-146, 2000.

3. Karbhari, V.M., Gao, Y. Composite jacketed concrete under uniaxial compression-verification of simple design equations. Journal of materials in civil engineering, 9 (4): 185-193, 1997.

4. Harajli, M.H., Hantouche, E. and Soudki, K. Stressstrain model for fiber-reinforced polymer jacketed concrete columns. ACl structural journal, 103 (5): 672, 2006.

5. Wu, G., Lu, Z., Wu, Z. Stress-strain relationship for FRP-confined concrete cylinders. In Proceedings of the 6th international symposium on FRP reinforcement for concrete structures (FRPRCS), Singapore 552-60, 2003.

6. Wei, Y.Y., Wu, Y.F. Unified stress-strain model of concrete for FRP-confined columns. Construction and Building Materials, 26(1): 381-392, 2012.

7. Saadatmanesh, H., Ehsani, M. R., Jin, L. M. Seismic Strengthening of Circular Bridge Pier Models with Fiber Composites. ACI Structural Journal, 93(6): 936947, 1996.

8. Chaallal, O., Shahawy, M., Hassan, M. Performance of axially loaded short rectangular columns strengthened with carbon fiber-reinforced polymer wrapping. Journal of Composites for Construction, 7(3): 200208, 2003.

9. Balsamo, A., Colombo, A., Manfredi, G., Negro, P., Prota, A. Seismic behavior of a full-scale RC frame repaired using CFRP laminates. Engineering Structures, 27(5): 769-780, 2005.

10. De Luca, A., Nardone, F., Matta, F., Nanni, A., Lignola, G.P., Prota, A. Structural evaluation of full-scale FRP-confined reinforced concrete columns. Journal of Composites for Construction, 15(1): 112-123, 2011.

11. Wang, Z. Y., Wang, D.Y., Sheikh, S.A., Liu, J.T. Seismic performance of FRP-confined circular RC columns. International Conference on FRP Composites in Civil Engineering, Beijing, China, 2010.

12. Ronagh, H.R., Eslami, A. Flexural retrofitting of RC buildings using GFRP/CFRP-A comparative study. Composites: Part B, 46: 188-196, 2013.

13. OpenSees. Open system for earthquake engineering simulation. Pacific Earthquake Engineering Research Center, University of California, Berkeley, USA, 2016.

14. Mander, J. B., Priestley, M. J. N. Theoretical stressstrain model for confined concrete. Journal of Structural Engineering, 114(8): 1804-1826, 1988. 
15. Lam, L., Teng, J.G. Design-oriented stress-strain model for FRP-confined concrete. Journal of Construction and Building Materials, 17 (6): 471-489, 2003.

16. $\mathrm{ACl}$ Committee. Building code requirements for structural concrete ( $\mathrm{ACl} 318-02)$ and commentary. American Concrete Institute, International Organization for Standardization, 2002.

17. BHRC. Iranian code of practice for seismic resistant design of buildings (Standard No. 2800). Building and Housing Research Center, Tehran, Iran, 2014.

18. Mahini, S.S, Ronagh, H.R. Web-bonded FRPs for relocation of plastic hinges away from the column face in exterior RC joints. Composite Structures, 93(10): 2460-2472, 2011.

19. Mostofinejad, D., Mahmoudabadi, E. Grooving as alternative method of surface preparation to postpone debonding of FRP laminates in concrete beams. Journal of Composites for Construction, 14(6): 804811, 2010.
20. Kent, D.C., Park, R. Flexural members with confined concrete. Journal of the Structural Division, 97 (7): 1969-1990, 1971.

21. Di Ludovico M, Prota A, Manfredi G, Cosenza E. Seismic strengthening of an under-designed RC structure with FRP. Earthquake Engineering Structural Dynamics, 37:141-62, 2008.

22. Inel M, Ozmen HB. Effects of plastic hinge properties in nonlinear analysis of reinforced concrete buildings. Engineering Structures, 28: 1494-502, 2006.

23. Tahghighi H. Earthquake fault induced surface rupture-A hybrid strong ground motion simulation technique and discussion for structural design. Earthquake Engineering and Structural Dynamics 40: 1591-1608, 2011.

24. TahghighiH. Simulation of strong ground motion using the stochastic method: Application and validation for near-fault region. Journal of Earthquake Engineering 16: 1230-1247, 2012.

25. Mortezaei, A., Ronagh, H.R., Kheyroddin A. Seismic evaluation of FRP strengthened RC buildings subjected to near-fault ground motions having fling step. Composite Structures 92: 1200-1211, 2010. 